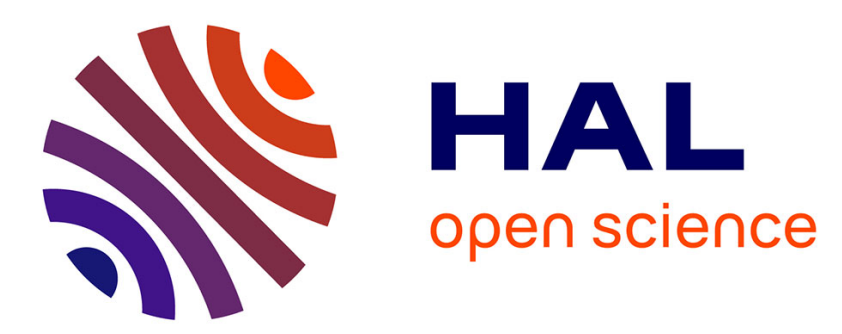

\title{
Did You Say Reference Conditions? Ecological and Socio-economic Perspectives on the European Water Framework Directive
}

\author{
Gabrielle Bouleau, D. Pont
}

\section{- To cite this version:}

Gabrielle Bouleau, D. Pont. Did You Say Reference Conditions? Ecological and Socio-economic Perspectives on the European Water Framework Directive. Environmental Science and Policy, 2015, 47, pp.32-41. 10.1016/j.envsci.2014.10.012 . hal-01098264

\section{HAL Id: hal-01098264 \\ https://hal.science/hal-01098264}

Submitted on 23 Dec 2014

HAL is a multi-disciplinary open access archive for the deposit and dissemination of scientific research documents, whether they are published or not. The documents may come from teaching and research institutions in France or abroad, or from public or private research centers.
L'archive ouverte pluridisciplinaire HAL, est destinée au dépôt et à la diffusion de documents scientifiques de niveau recherche, publiés ou non, émanant des établissements d'enseignement et de recherche français ou étrangers, des laboratoires publics ou privés. 


\title{
Did You Say Reference Conditions? Ecological and Socio-economic Perspectives on the European Water Framework Directive. G. Bouleau - IRSTEA BORDEAUX UR ETBX FRA D. Pont - IRSTEA ANTONY UR HBAN FRA
}

\author{
Introduction
}

The European Water Framework Directive ${ }^{1}$ (WFD) aims to protect and improve the ecological status of aquatic systems in order to promote sustainable watershed use and ensure an adequate water supply. In all cases, Member States must reduce the use of hazardous substances and ensure that water pricing encourages conservation. Each Member State must define water quality objectives for every water body (river or consistent hydrogeological unit) within its jurisdiction, conduct a watershed assessment, and prescribe appropriate restoration measures within a given timeline. Member states and the Commission agreed upon a common implementation strategy, with a EU team of national experts working together in order to ensure harmonization across national assessment methods of water ecological quality. This process is known as the intercalibration exercise and is less than half completed (Birk et al., 2013).

The assessment of the ecological status of a water body is a relatively new and innovative policy for water quality management; earlier directives merely imposed standards for water chemistry and only targeted the waters used for specific purposes. The integration of biological criteria with water quality standards raises questions about how to quantify and assess biodiversity in aquatic ecosystems and how to address changes in those systems over time.

In this paper $^{2}$, we combine perspectives from sociology and ecology to examine the concepts and tools associated with the WFD and identify challenges to implementing the WFD in the context of global climate change. We are particularly interested in the evolution of technical terms used by the scientific community over the last 20 years of WFD discussion and implementation to describe the concepts of reference conditions and the precautionary principle, from the production of the first version of the WFD in 1994 through the end of the European bioindicator intercalibration in April, 2012. We argue that such concepts used in the WFD are hardly grounded in current ecological theories and are difficult to apply in a context of changing environment and long-term interactions between man and nature. But they corresponded to specific needs from different institutions and stakeholders which promoted them. By integrating insights from multiple disciplines, we can identify the practical advances made possible by the WFD and build a foundation for developing management guidelines in the future.

We mainly focus on the use of reference condition in relation with biological indicators because the ecological assessment of water bodies, in comparison with the chemical assessment, is one of the most innovative characteristic of the WFD.

\section{Reference conditions: a historically situated policy concept}

The Water Framework Directive provides a specific framework for evaluating water policies: 1) water quality objectives must be set in relation to reference conditions; 2) actions to

\footnotetext{
${ }^{1}$ The Water Framework Directive (2000/60/EC) was adopted on October 23, 2000 by the European Parliament and the Council. It established "a framework for community action in the field of water" (L 327, 22/12/2000, p. 0001 0073).

${ }^{2}$ This paper is an extended and adapted version from a paper published in French: Bouleau, G., Pont, D., 2014. Les conditions de référence de la directive cadre européenne sur l'eau face à la dynamique des hydrosystèmes et des usages. Natures Sciences Sociétés 22 (1), 3-14.
} 
achieve the objectives must be compared in terms of cost and efficiency; and, 3) water quality data must be systematically collected and made public. Through this process, the European WFD regulations aim to make water-related policies more accountable, particularly to funders, in the form of quantitative indicators. The concept of reference conditions had never been used before the WFD in European water policy. We argue that it is a historically situated concept which corresponds to specific needs of the actors who promoted the WFD. The "driving-forces, pressures, state, impact, response" conceptual model that also imbues the WFD has older roots, but it similarly met some of the needs of the WFD writers.

This concept filled a policy loophole, i.e. the lack of standard for natural waters. The European water quality policy first developed with a command and control approach regulating specific pollutants. This approach, often referred as the classic "community method" (Scott and Trubek, 2002), prevailed in European environmental policy until the late 1990s. It imposed strict legally-binding standards based on chemistry whose enforcement was deemed easy to verify (Homeyer, 2004). A first wave of directives (1973-1988) produced a "kaleidoscope" of sector regulation (Aubin and Varone, 2004; Santbergen, 2013). Since the early 1980s, highly regulated Member States have further pushed for regulating all surface waters with strict rules complying with their domestic legislation in order to protect their industry, to avoid administrative cost of adaptation, and to value their first-mover advantage. In the aftermath of Seveso and Sandoz accidents, these "leaders" found political support in environmental NGOs and the European Commission (EC) (Dezalay, 2007) while their opponents remained isolated in the Council of Ministers or in the Parliament (Héritier, 1995; Sbragia, 1996). The scope of the second wave of directives (1988-1991) regulated waste waters and natural waters affected by eutrophication. However, Member States could restrict the implementation of these directives to specific zones. In 1994, many natural waters remained out of the scope of European law.

Michelle Cini (1995) studied how employees of the Directorate-General for the environment (DG Environment) of the EC promoted the precautionary principle. She noticed that they developed a specific political discourse of ecological modernization which reconciles economic growth -a dominant motto in other DG- with environmental conservation in a specific manner. It consists in arguing that some elements of the environment are vital for human survival and must be protected at all costs by precaution, while the protection of others may be subjected to cost-benefit analyses. The WFD is influenced by this discourse. It prohibits the use of hazardous substances. It holds that the good ecological status must be achieved whatever the cost, except for the water bodies that are highly modified by profitable activities.

In drafting the ecological quality of water directive (EQW), EC policy-makers targeted uniform and legally-binding European water quality standards. For chemical parameters, they set a baseline of zero contamination, which was the $\operatorname{OSPAR}^{3}$ environmental quality goal for the marine environment (Howarth, 2006). A similar uniform baseline in ecology was yet lacking. The EQW draft (Commission of the European communities, 1994) did not set ecological requirements in quantitative terms. It integrated aesthetic and natural heritage considerations into restoration objectives. The focus was primarily on water quality and secondarily on biological connectivity in river systems. The term "reference conditions" was not used. The text prescribed high ecological water quality and sediment quality as meeting the needs of the ecosystem, especially the capacity for "self-purification", high level of biological diversity (aquatic plants, invertebrates, fish, amphibians, mammals and birds), and the absence of toxics and diseases linked to human activities. The objectives were articulated in terms of hydrosystem functions and

\footnotetext{
${ }^{3}$ The Convention for the Protection of the marine Environment of the North-East Atlantic
} 
services, rather than descriptors of biological communities. Each Member State was responsible for developing its own definition of "good conditions" and for implementing restoration measures.

In the following years, despite Council rejection of the text, policy-makers in DG Environment went on looking for more quantitative binding ecological standards and selected a small group of scientists willing to proceed in this direction (Loupsans and Gramaglia, 2011). The outcome of this process is Annex V of the WFD. Reference conditions can therefore be understood as a political concept EC policy-makers needed to anchor a uniform norm-setting for all European surface waters to ecology. However, the adoption of the concept in the WFD did not follow a linear path.

In 1995, the Dutch, French and British governments challenged the EQW directive and the classic community method for water policy all together. They released several position papers pointing the lack of coherence among existing EU water policy. They managed to convince the EC to adopt an integrated strategy, that would give Member States more flexibility in setting environmental standards and optimizing ways of goal attainment (Dezalay, 2007; Santbergen, 2013:115-6). The drafting of the WFD followed. In 1998 and 1999, the Council tried to get rid of legally-binding ecological objectives but the Parliament reintroduced them during the codecision procedure (Kaika and Page, 2003). The Council eventually accepted this clause because the WFD included intrinsic exemptions (Article 4) offering ample provisions for local adaptation to regional conditions and economic considerations. The resulting ambition of the WFD is highly ambiguous, leaving many choices and interpretations open for the implementation phase (Barone and Bouleau, 2011; Hering et al., 2010; Junier et al., 2011; Keessen et al., 2010; Santbergen, 2013).

While the ecological content of the WFD (Annex V) is still framed according the community method, the rest of the WFD instead corresponds to a new governance model (Scott and Trubek, 2002), with a focus on implementation procedures, such as consultation requirements, transparency concerns, and reporting obligations. Santbergen (2013) argues that this part of the WFD shows a strong influence of the British philosophy for managing the environment at the most cost-effective way (Dezalay, 2007; Knill and Liefferink, 2007). Indeed, the WFD holds that Member states shall "make judgments about the most cost-effective combination of measures" (Annex III). Comparing the cost-effectiveness of different measures requires a common "reference", which does not need to be a uniform ecological baseline throughout Europe. However the concept of reference conditions could do the job in combination with a general framework for comparing options of restoration. In the environmental field, the OECD developed such a conceptual framework (pressure, state, response) in 1993 to compare management actions (responses) that aim to reduce impacting activities (pressures) to achieve a desired state (OECD, 1993, 1994). This framework was subsequently amended (driving forces, pressure, state, impact, response or DPSIR) by the European Environment Agency and used to assess the state of European water bodies and the effectiveness of water quality policies (EEA, 1995). The DPSIR model is a method for cost-benefit analysis based on mitigation logic (Fernandez et al., 2014). The model aims to compensate for pressure from socioeconomic forces by using political and economic responses to influence human activities and prevent environmental degradation. Pressures and responses are made commensurable by selecting appropriate indicators. The logic of this model underlies the entire WFD, as evidenced by the high occurrence of the terms "impact" (67) "pressures" (26), "status" (242) and "measures" (126) 
in this context in the English version ${ }^{4}$. Apart from a few restrictions (see Part 4), the directive requires programs of measures (Art 11 of the WFD) to mitigate for "inevitable" pressures (see Figure 1). This model of compensation hinges on the target of the good state for each body of water, which is defined by a non-significant deviation to a reference value on the scale, and which is achieved through restoration actions.

Last but not least, the concept of reference conditions helps coordinating the work of expert committees towards a unified monitoring network. This issue was addressed in the intercalibration exercise which "yielded a fundamental and unified vision of what constitutes good ecology across Europe" (Birk et al., 2013). It is based on a "significant level of statistical abstraction" (ibid. :490) which contrasts with compliance indicators used in the classic community method that were easy to verify. Intercomparability (of waterbodies) and intercalibration (of indicators) raised technical stakes hardly accessible to the general public. Only experts commissioned by Member States may learn from each other through this process. This relates to the open method of coordination (Kraemer et al., 2004 ; Radaelli, 2003) inscribed in the Lisbon Strategy, which seeks Member States convergence through benchmarking rather than compliance to binding standards.

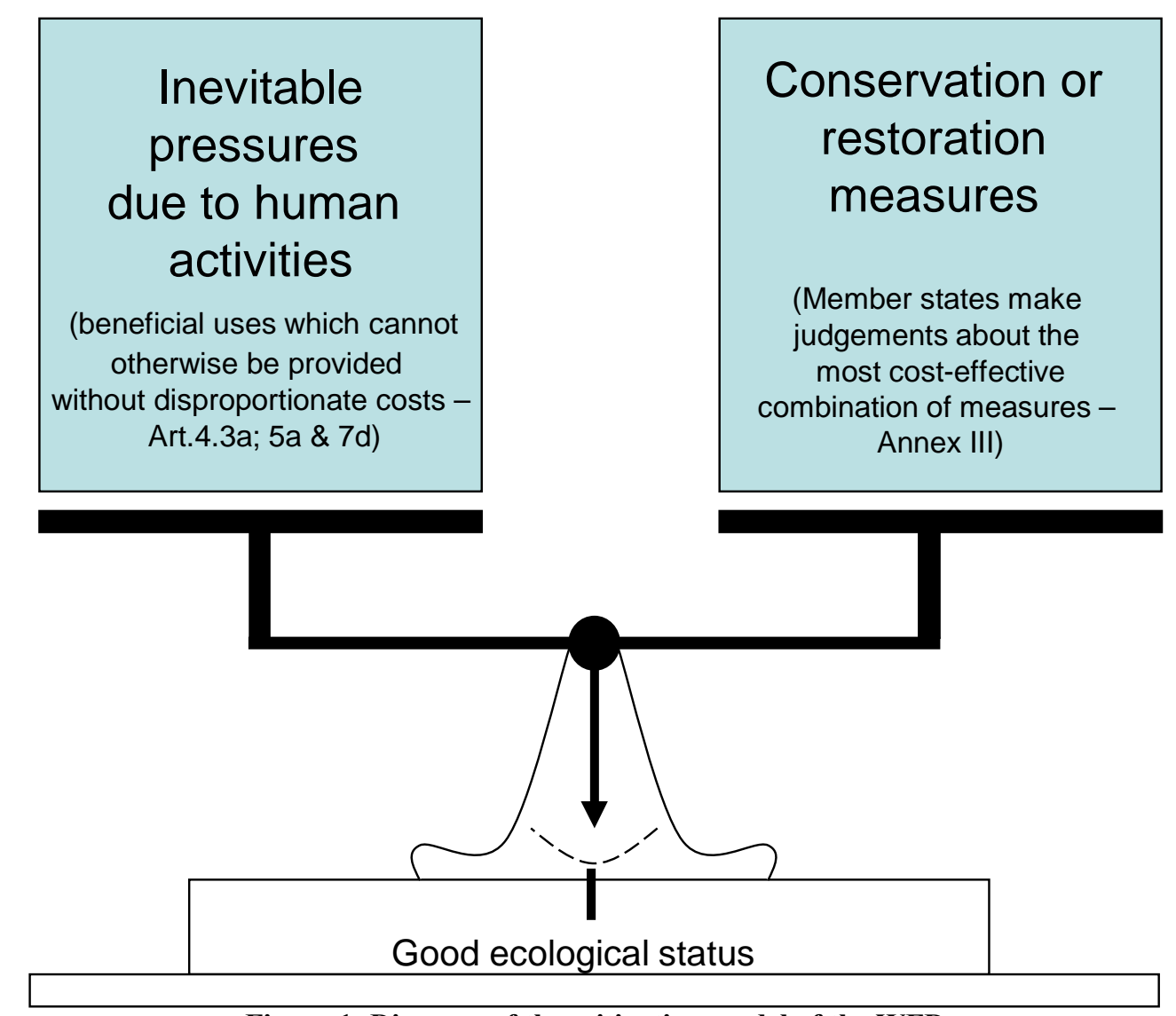

Figure 1: Diagram of the mitigation model of the WFD

\footnotetext{
${ }^{4}$ The word 'status' is used in the WFD to refer to the environmental conditions of a water body, and the word 'measures' refers to actions by States to restore the desired environmental conditions, i.e. the environmental state and the responses in DPSIR language.
} 
The socio-historical background on environmental public policy given above allows us to understand the inclusion of the reference conditions concept in the WFD as a flexible concept that was compatible with three different philosophies: setting legally-binding standards, assessing the cost-effectiveness of measures, and coordinating the implementation of Member States with common benchmarks. . In Europe, the conceptual framework of the WFD was met with enthusiasm by several national organizations, which are responsible for the management of aquatic ecosystems, including river basin authorities and environmental agencies. Members of these organizations have long sought an economic argument to justify the protection of the environment and help establish priorities. However, the conceptual design of the WFD probably would not have withstood criticism from skeptics (Moss, 2008)had it not also received input from other experts in building its quantitative methodological framework (scale of measurement, benchmarks and set of metrics).

\section{Implementing the reference conditions as an operative concept in the WFD}

The WFD defines the reference conditions for an ecological system as the conditions that prevail in the absence or near absence of human disturbance ${ }^{5}$. This corresponds to hydromorphological, physico-chemical and biological characteristics of "undisturbed," pollutant concentrations close to zero, and synthetic and non-synthetic pollutants at levels below "background noise." To assess ecological characteristics, a regionalized aquatic typology is used that accounts for variation in biodiversity due to ecoregional characteristics (hydro-climatic, physical habitat and biotic trophic factors) in water bodies of a similar size (Hughes and Larsen, 1988; Omernik, 1987). A 'good condition' refers to any size of deviation from the reference typology that does not lead to significant changes in biological communities. A more significant deviation is interpreted as a sign of disruption of the key factors that determine local biodiversity. This approach assumes a possible return to a 'good condition' if the cause of disturbance is suppressed, provided the disturbance has not caused irreversible harm.

This definition of an ecologically 'good condition' is similar to that used in the United States in the Clean Water Act of 1972 (U.S. House of Representatives, 1972). It refers to the "natural" character of the ecosystem (its structure and function) and is directly linked to the concept of biotic integrity (Karr, 1981). Recently, this concept and the criteria for evaluating a deviation from reference conditions have been codified in the United States (Davies and Jackson, 2006) and Australia (Water Reform Framework in Stoddard et al., 2006) . The description of the reference condition is based on knowledge of sites with desired characteristics. This can include knowledge of "pristine" (that is to say, "untouched") sites, but may also include historical knowledge, or even expert opinions or the results of simple modeling techniques.

The concept of reference conditions has been used for many years in other fields like forest ecology and paleolimnology, (Swetnam et al., 1999). Interdisciplinary approaches are used to describe changes in ecosystems and/or landscapes over the long term (up to millennia). Such reconstructions have driven the evolution of a new academic field, "applied historical ecology," which explicitly uses the concept of reference conditions to guide restoration actions and the management of natural systems (Egan and Howell, 2001). In forest ecology, historical reference conditions are viewed as reflecting the long term variability of the structure, composition and process of ecosystems over time (Fulé et al., 1997), providing insights to natural disturbance

\footnotetext{
${ }^{5}$ The terms 'disturbed,' 'undisturbed' or 'disturbances' are used a total of 107 times in Annex V of the WFD, without being clearly defined.
} 
regimes (Kaufmann et al., 1998). Reference conditions are reconstructed from multiple sources depending of the spatial and temporal scale considered (documentary archives, dendrochronology, palynology, remote sensing...).

In comparison, Annex V of the WFD relies upon an assessment of the deviation from a state of stable reference conditions ${ }^{6}$, which are defined using criteria related to species abundance and taxa richness associated with regional environments. In the WFD, the biological indicators are restricted to aquatic environments. Hydro-morphological alterations are more taken into account in the WFD than in the EQW directive. As a result, the WFD definition of environmental objectives is imbued with what Steyaert and Ollivier (2007) named a "communitarian perspective" on environmental objectives, which excludes "human activities to build up the reference conditions of water" and gives "advantage to the pristine model of nature". This model is consistent with the concept of reference conditions. Considerations for humans are not to be found in the ecological part of the directive but in the economic part, which in contrast is inspired by a "utilitarian perspective" (ibid.;Bouleau, 2008). In contrast with the EQW directive the WFD abandons natural heritage and aesthetic considerations and does not consider any more the terrestrial part of the fluvial corridor (riparian zone, bird, amphibians and mammals). The division of labor between ecology, which is responsible for determining environmental standards, and economics, which is responsible for optimizing regulations by determining prices once standards are set, corresponds to the neoclassical school of environmental economics (Anderson and Leal, 1991).

Developing ecological standards raises the question of their social legitimacy. Why would some ecotypes, species or functions be preserved and not others? Historically, ecological indicators were constructed to quantify problems that were of public concern at specific scales and over certain time periods (Bouleau et al., 2009; Turnhout, 2009). These indicators would not necessarily be appropriate at other spatial-temporal scales. The definition of "good" in the WFD aimed to standardize the various national methods of assessment and make a "good condition" in hydrosystems comparable across all Member States (i.e., the European intercalibration process). In practice, the implementation of these principles has been extremely variable from State to State based on the availability of data and resources, the bio-indicators and types of water bodies considered, and even the pre-existing schools of thought among freshwater biologists and managers.

"Reference conditions" are alternatively defined by Stoddard, et al. (2006) as:

- The biotic integrity or "natural" state for which long-term variability is acceptable within relatively narrow limits (steady state).

- A state corresponding to conditions encountered in minimally disturbed areas. Here we accept minimum disturbance over large areas.

- A condition or state that existed prior to any human modification considered "important" by the authors. For example, Wallin et al. (2003) consider the period prior to the development of intensive agriculture and/or industrialization (circa 1850 in England and 1750 in Germany) to be the reference condition, regardless of previous human impacts ${ }^{7}$.

\footnotetext{
${ }^{6}$ The drafters of the WFD were aware that there would eventually be changes (spontaneous or anthropogenic) in ecological status (see infra note 8). In their minds, however, these changes would occur slowly over time and would not call into question the purpose of restoration.

${ }^{7}$ These approaches do not take into account the effects of shifting cultivation or medieval land clearing on hydrosystems.
} 
- The least disturbed condition in a given area. Criteria (water quality, development, land use, etc.) are defined and used to select sites.

- The best state potentially achievable. This is the state that one can expect to achieve at a relatively degraded site if one applies all possible management measures in terms of ecological restoration (for example, in the Netherlands).

This diversity of approaches reflects the contrasting views among the ecologists and scientists who were involved in the translation of the WFD into operational terms. The most common existing approach is the selection of conditions that are minimally disturbed or undisturbed based on certain anthropogenic pressures. Germany and Austria more strictly refer to the concept of biotic integrity, combining historical and expert approaches (Schmutz et al., 2000). The recent intercalibration exercise conducted in Central-Baltic region of Europe revealed that the pressure criteria used to select reference sites needed further standardization (Pardo et al., 2012).

It is interesting to note that this difficulty in calibrating definitions is not an isolated case in European policy. Robert Salais, who is interested in the implementation of the Lisbon Strategy in employment issues, pointed to the lack of a common definition of unemployed or employed (Salais, 2004). Isabelle Bruno, who studied equal opportunity policies for men and women and programs for financing pensions, also noted that common definitions were very blurred in those policy fields (Bruno et al., 2006).

\section{The ecological roots of the reference condition concept}

The WFD appears to have been largely inspired by an old ecosystem paradigm that is based on an a priori vision of nature centered around species (Clements, 1905; Elton, 1930; Tansley, 1935). Under this paradigm, each ecological unit is considered relatively constant in the face of environmental variability and is able to regulate itself, much like an organism (the "balance of nature" concept). Natural ecosystems move through a series of phases to reach a climax state, where they remain until there are major changes in the global environment on a large temporal scale. Ecosystems are predictable, although disturbance cycles are integral to the way they behave (following disturbance, ecosystems return to their previous "optimal" state). Odum (1953) and Whittaker (1975) popularized this concept and its associated holistic vision of ecosystems. The concept of reference conditions is grounded in this idea of a stable state. But the ecosystem paradigm described above has been challenged in recent decades on the grounds of i) species dispersal and metapopulation theory (Hanski, 1999), and ii) the role of spatial heterogeneity on ecological process and the importance of flux in landscape between ecosystems (Pickett and Cadenasso, 1995). Ecosystems are now seen as unstable, open, hierarchical and scaled (O'Neill, 2001). The most important for our discussion is to call into question the idea of ecosystems as stable and predictable.

Initially, the concept of "resilience" accounted for variability in a system in a steady state by explaining the variability as a response to small perturbations. The resilience concept addressed variability in terms of return time to a stable state (Pimm, 1984) and suggested that there was a maximum level of disturbance that could be tolerated without significant alteration of functions (Holling, 1973). More recently, as a response to repeated failed restoration efforts that have highlighted the irreversible nature of many of the changes sustained by natural systems, Scheffer et al. (2001) proposed the concept of alternative stable states. Even in response to a continuous gradient of environmental change (natural or human-induced), ecosystem change occurs 
dramatically in a non-linear process from a given point. Ecosystems are not able to return to their original state when previous environmental conditions are restored. Multiple different stable states may persist in a single ecosystem. This theory identifies non-linear, and even "chaotic" systems-theory-based pathways of ecosystem change. In particular, river landscapes experience a complex entanglement of long-term and short term fluctuations which make idealistic to consider reverting to any previous stage, pristine or not (Dufour and Piégay, 2009).

From a conceptual standpoint, climate change sheds light on the contradiction between the reference conditions concept and the dynamic trajectories of aquatic ecosystems. The consequences will be important for the distribution of many species, especially cold water species. Accessibility to refuge areas during periods of stress (i.e., low flow and thermal peaks) will become a major factor in maintaining these populations (Buisson and Grenouillet, 2009; Pont et al., 2006). Climate change will not only change the ecological status of undisturbed areas, but will also interact with the impacts of human activities on biological communities (e.g., eutrophication and the coupling of thermal regimes and hydrology) and will exacerbate the uncertainties associated with the monitoring and assessment ((European communities, 2009). It is likely that the so-called reference biological communities are evolving and simulation exercises demonstrated the potential impact on the assessment of ecological status (Logez and Pont, 2013).

Another major challenge to the concept of reference conditions stems from the observation that significant environmental modifications by humans have occurred for several millennia. The notion of an undisturbed state no longer has ecological significance. Expanding upon the original concept of an ecosystem, the socio-systems concept (Fischer-Kowalski, 1997) recognizes the inseparability of natural and social aspects of these systems and the central role of humanenvironment interactions. In the academic field of environmental history, and more specifically history of ecology, there is an underlying premise that man and nature have co-evolved since Neolithic times.Human activities are not always perceived as synonymous with destruction (Balée, 1998). Rather, it is recognized that human activities could also create, through long-term interactions with nature, cultural landscape having an higher value of biodiversity (Balée, 1998; Farina, 2000).

The distinction between natural and human-altered states is misleading. It implies that one can separate ecosystem characteristics that result directly from human actions from those which are natural characteristics of a dynamic system. Identifying human-induced characteristics is relatively possible at the local level, provided that managers allocate resources to making human impacts publicly visible and measurable with ecological status indicators (Bouleau et al., 2009). In contrast, for rivers that continuously experience flooding and chemical inputs from upstream, the millennial transformation of watersheds by humans (including changes to forest cover) make it impossible to define an ecosystem state that has not been impacted. A recent case study of the Drôme River, southeast France, shows the temporal succession of interactions between land drainage and river basin dynamics (Pont et al., 2009). Gunderson and Holling (2002) proposed the concept of panarchy to account for the complex natural and human dynamics of watersheds. In a related discussion, Lévêque et al. (2003) suggest the term anthroposystem. The dynamics of ecological systems can no longer be explained using bio-physico-chemical rules alone, and the distinction between natural and anthropogenic forces is artificial.

In a critical analysis of the WFD, Steyaert and Ollivier (2007) conclude that the ecologists who participated in the writing of the text were overwhelmingly influenced by the concept of ecosystem stability and focused on systematically considering human activities as disturbance 
factors. Recently, Dufour and Piégay (Dufour and Piégay, 2009) proposed to replace the restoration strategy aimed at achieving a defined, "natural," ideal ecological state (referencebased strategy, stemming from Leitbild (Kern, 1992a)) with a strategy that defines objectives based on the services provided by ecosystems.

\section{Towards biological indicators based on functional criteria}

In parallel to the drafting of the WFD, a conference, which took place in Vienna in 1998, focused on assessing the ecological integrity ${ }^{8}$ of rivers (Jungwirth et al., 2000)and developing WFD-compliant biological assessment methods (Jungwirth et al., 2000). Most of the biological indicators presented were based on a static description of aquatic communities (micro and macro algae, invertebrates, fish) and by grouping water bodies into discrete categories (river zonation system). As the reference condition concept, these biomonitoring tools rely mainly to the long obsolete concept of climax (see before) and do not consider the modern idea of species turnover and continua of community structure along environmental gradient (Friberg et al., 2011).

Aquatic ecologists have expressed many criticisms about the lack of functional criteria used in such biological indicators (Friberg et al., 2011), both for conceptual reasons and because of the current emphasis on expert opinion. However, in spite of awareness about the limitations of the conceptual approach of the WFD, many European scientists paint a more positive picture of the first ten years of implementation of the directive (Hering et al., 2010). One main reason is that the implementation of the WFD has led to the establishment of networks of biological monitoring that use more standardized sampling techniques. Although the requirements outlined in the directive are based on a limited number of biological (and chemical) indicators, this has the advantage of focusing members' efforts on specific common protocols, thereby helping to improve the methods. The need to standardize methods across European countries has led to unprecedented development of international discussion and collaborative research projects, including more than 1100 publications related to the WFD in 10 years (Web of Science, July 2009). Because the WFD approach was very pragmatic, it was possible to apply it in most countries, despite its shortcomings. The implementation of the WFD has greatly improved the degree of comparability of the ecological quality of rivers across Europe.

Moreover, it should also be noted that most of recent WFD-compatible bioindicators are no more based on floro-faunal lists, but on functional criteria determined by ecological and/or biological characteristics. This is particularly the case in France for fish (Oberdorff et al., 2002) and invertebrates (Mondy et al., 2012). For example, a high level of omnivory is indicative of degradation, while specialization in breeding habitats indicates a low degree of physical alteration of the environment. The first advantage of these functional-type's indicator is that, by removing the taxonomic specificity, they can be used on a much wider geographic scale (i.e. the European scale) which solve the problem of intercalibrating the different national methods. The development of a paneuropean fish index (Pont et al., 2006) demonstrated its feasibility even if the counterpart is a relative lack of sensitivity to some specific local situations. The second

\footnotetext{
${ }^{8}$ The concept of biotic integrity is of American origin and was popularized in Europe in the late 1980's in Germany and Austria. It is based on a vision or Leitbild for a specific river reach, primarily defined by reference to the florofaunal structures pre-dating industrialization. (Kern, K., 1992b. Rehabilitation of streams in South-western Germany, In: Boon, P., Calow, P., Petts, G. (Eds.), River Conservation and Management. John Wiley \& Sons, Chichester, pp. 321-335.)
} 
advantage is that the relation between stressor and response can be predicted based on clear mechanisms of cause-effect. Nevertheless, in the case of these functional-type bioindicators, the functions are only considered indirectly via the definition of functional specific guilds and bioindicators purely based on functional descriptors of ecosystem remain to be developed in the future.

Another major improvement is to not use any more typologies and pre-defined community types but to consider more realistic gradient-based measure of community change. The RIVPACS method was the first to attempt to predict, using site-specific variables, the expected macroinvertebrate community in the absence of disturbance and to compare with the observed one (Wright et al., 1993). Using both ecological-biological traits and modelling approach, Oberdorff et al. (2002) and Pont et al. (2006) proposed multimetric predictive indexes to model the functional characteristic of fish assemblages in the absence of disturbance and to assess the ecological status of rivers.

In a recent work, Marzin et al. (2014) developed a new predictive multimetric index considering the climatic conditions (air temperature and rainfall) prevailing during the ten years before the assessment period and associating an uncertainty to the ecological assessment of each site. In complement to establish long-term monitoring network, such tool could allow better considering the changing nature of the environment.

Nevertheless, the capacity of biological indicators to identify the precise causes of degradation remains questionable. The authors of the WFD assumed a direct relationship between a pressure and a set of indicators, which has been shown to be false for several reasons. They overestimated the capacity of biotic indicators to respond to different pressures in specific ways. Except for few cases, such as the response of phytoplankton to increased phosphorus levels, indicators generally respond to the different types of pressures (Marzin et al., 2012) like water quality degradation and hydromorphological alteration. The results of the European intercalibration process showed that there were significant relationships between the sensitive bio-indicators and the main types of pressure, but these relationships were not as strong as national experts had previously suggested (Pont, 2011). This result is also due partly to the large uncertainties associated with the assessments (Clarke and Hering, 2006; Marzin et al., 2014). And finally, most of rivers are affected by multiple pressures involving both the degradation of water quality and changes in stream morphology and hydrology (Ormerod et al., 2010).

\section{Summary and conclusions}

The ambition to monitor the ecological conditions of all surface waters, rather than simply considering the physico-chemical qualities of some waterbodies, represents real progress from an environmental point of view. Nonetheless, the approach used by the WFD poses serious problems. Some of the problems are relatively new, and some have not yet been overcome, even fourteen years after the publication and implementation of the WFD.

The WFD is an ambiguous piece of law which includes legally-binding provisions in line with the classic community method and a much more flexible framework for comparing and assessing policy options based on economic criteria in line with new form of environmental governance. Both policy models require defining quantitative indicators. Yet the drive for establishing reference conditions relates to the legally-binding character of the WFD objectives. From the ecological point of view, the idea of stable reference conditions refers mainly to the concept of ecosystems reaching a "climax" state. It contradicts all the modern concepts in 
ecology, underestimates the continuously evolving nature of our environment and does not consider the long term interactions between man and nature. It should be noted, however, that the relative stability of an ecosystem over a discrete time period is often a useful reference for detecting and measuring a local change.

Conceptual debates about reference conditions do not prevent its implementation. Approaches to "identifying" reference conditions are usually pragmatic. Reference conditions are typically identified by examining relatively undisturbed sites based on a review of human pressures, without actually seeking to define a common theoretical vision. This approach has been applied in a variety of situations by adjusting the historical reference period, the frequency of measurement, and the sampling locations to characterize a particular ecological impact that posed a social problem. In practice, the new governance component of the WFD allowed experts to define an evaluation framework, identify impacted sites, and prioritize restoration actions to address those sites. The intercalibration process remains obscure for most lay people, but led most Member States to a pragmatic approach. It consisted, at a minimum, to set common reference conditions based on networks of undisturbed sites. In addition, the new generation of bio-indicators based on "functional" characteristics of biological communities is better able to provide a comparative analysis of water bodies at the European scale.

With regards to climate change and the assessment of ecological status, additional macroenvironmental variability resulting from climate change in the future will further challenge the use of the concept of reference conditions. However, the limited duration of the WFD time frame (2000-2027) could allow for revising local reference conditions to take into account new information about regional environmental conditions (monitoring networks, modeled reference conditions $)^{9}$. In their management plans, Member States should at least assess the implications of climate change in the context of other anthropogenic impacts, consider climate change in their monitoring programs, and develop plans based on resilience strategies. The plans should favor restoration projects that implement "no regrets" measures, i.e., measures that are sufficiently reliable and robust to remain viable in a changing global context and that are not likely to counteract measures taken by other parties to mitigate the impacts of climate change (e.g. reestablishment of connectivity within river network in order to facilitate species migration, riparian forest development).

But the reference conditions issue will resurface at the next stage of implementation of the WFD as the primary objective of the management plans moves from assessment to restoration (2015-2021 and 2021-2027). One of the guiding principles for restoration actions is that the re-establishment of historical abiotic conditions and their associated disturbance regimes will result in the recovery of biological communities prevailing before degradation. This explicitly invokes the principle of community succession (and successional-based management efforts). In reality, however, the results of restoration projects are often not what we expect, and the system does not return to its previous state (Suding et al., 2004). This result can be explained by the lack of existing systems that can be used to define reference conditions; changes in conditions at large scales (landscape, watershed, and climate); an irreversible modification of certain environmental parameters; changes in connectivity at the basin scale; changes in the migration of species; and new biotic interactions and the alteration of biotic-abiotic feedbacks,

\footnotetext{
${ }^{9}$ Annex V (1.3.1) states that Member States must establish monitoring programs to collect data that will be used to evaluate changes in natural conditions over the long term.
} 
which causes lasting changes in bio-geochemical conditions (Henri and Amoros, 1995; Nilsson et al., 2007; Suding et al., 2004).

It is worth noting that the use of reference condition concept in WFD is more linked to stability and reversibility than in the thoughts of forest ecologist in North America (Fulé et al., 1997). Reversibility concept remains acceptable when considering local and short term perturbations (e.g. recovery of a river from a local source of organic pollution), but is questionable when i) numerous anthropogenic pressures are acting on the whole catchment and ii) long term land use evolutions within a catchment have altered the large scale processes controlling the fluvial dynamic (e.g. trying to revert a river stretch to a previous braided state when the coarse sediment bed load is nowadays limited due to afforestation).

One possible future strategy for restoration could combine considerations for ecosystem health, ecosystem services, and productivity in a sustainable manner for social benefit (Aronson et al., 2006). Identifying society's needs would require a more important participation of managers, users and stakeholders at different levels (Dufour and Piégay, 2009). Historical trajectories of systems remain an important point when targeting a better knowledge of the main processes to be restored. Due to the complex dynamic of ecosystems, it is necessary to consider ecological, social and economic values and the uncertainties about restoration objectives (Hughes et al., 2005), Adaptive management, a problem-solving environmental management approach (Aronson et al., 2006), appears as a promising way to handle restoration of European water bodies in the context of the WFD. In all cases, historical trajectories of systems help understanding the main processes to be restored. This knowledge is crucial when confronting society's demands and potential functioning. An interesting direction for future research would be to see how different social groups implement the WFD and its tools (monitoring networks, expertise, concepts, planning documents, and decision steps) for guiding future decisions about the environment in a changing context.

Acknowledgments

This research was conducted in part with the support of the French National Research Agency (ANR), within the MAKARA project (Societal responses to surface water « quality » Changes: France, 19th-20th centuries) of the program "Sociétés \& changements environnementaux 2012" (contract ANR-12-SENV-009). It has been also supported by IRSTEA within the project CHIFFRE (APR Indeco 2012) and by the European REFORM project (European Program FP7-ENV-2011, contract No. 282656, "REstoring rivers FOR effective catchment Management").

\section{References}

Anderson, T., Leal, L., 1991. Free Market Environmentalism. Westview Press, Boulder.

Aronson, J., Clewell, A.F., Blignaut, J.N., Milton, S., J, 2006. Ecological restoration: a new frontier for nature conservation and economics. Journal for Nature Conservation 14, 135-139.

Aubin, D., Varone, F., 2004. The evolution of the European Water Policy. Towards an integrated resource management at EU level, In: Kissling-Näf, I., Kuks, S. (Eds.), The evolution of national water regimes in Europe: transitions in water rights and water policies. Euwareness. Kluwer Academic publishers, pp. 49-89.

Balée, W., 1998. Advances in Historical Ecology. Columbia University Press, New York.

Barone, S., Bouleau, G., 2011. La directive-cadre sur l'eau et ses traductions : que nous apprennent les sites 'innovants' ? Pôle Sud 35, 43-58. 
Birk, S., Willby, N.J., Kelly, M.G., Bonne, W., Borja, A., Poikane, S., van de Bund, W., 2013. Intercalibrating classifications of ecological status: Europe's quest for common management objectives for aquatic ecosystems. Science of The Total Environment 454-455 (0), 490-499.

Bouleau, G., 2008. The WFD Dreams: between ecology and economics. Water and Environment Journal 22 (4), 235 - 240.

Bouleau, G., Argillier, C., Souchon, Y., Barthélémy, C., Babut, M., 2009. How ecological indicators construction reveals social changes - the case of lakes and rivers in France. Ecological Indicators 9 (6), 1198-1205.

Bouleau, G., Pont, D., 2014. Les conditions de référence de la directive cadre européenne sur l'eau face à la dynamique des hydrosystèmes et des usages. Natures Sciences Sociétés 22 (1), 314.

Bruno, I., Jacquot, S., Mandin, L., 2006. Europeanization through its instrumentation: benchmarking, mainstreaming and the open method of co-ordination... Toolbox or Pandora's box? Journal of European Public Policy 13 (4), 519-536.

Buisson, L., Grenouillet, G., 2009. Contrasted impacts of climate change on stream fish assemblages along an environmental gradient. Diversity and Distributions (15), 613-626.

Cini, M., 1995. Administrative Culture in the European Commission: the case of competition and environment, European Community Studies Association (ECSA), Fourth Biennial International Conference, Charleston, South Carolina, USA.

Clarke, R.T., Hering, D., 2006. Errors and uncertainty in bioassessment methods -major results and conclusions from the STAR project and their application using STARBUGS. Hydrobiologia $566(1), 433-439$.

Clements, F.E., 1905. Research methods in ecology. University Printing, Lincoln, Nebraska, USA.

Commission of the European communities, 1994. Proposal for a council directive on the ecological quality of water, COM (93). Brussels. 94/0152 SYN.

Davies, S.P., Jackson, S.K., 2006. The biological condition gradient: a descriptive model for interpreting change in aquatic ecosystems. Ecological Applications (16), 1251-1266.

Dezalay, Y., 2007. De la défense de l'environnement au développement durable. L'émergence d'un champ d'expertise des politiques européennes. Actes de la recherche en sciences sociales 1 (166-167), 66-79.

Dufour, S., Piégay, H., 2009. From the myth of a lost paradise to targeted river restoration: forget natural references and focus on human benefits. River Research and Applications. (25), 568-581. EEA, 1995. Inland Waters - Europe's Environment: The Dobris Assessment 1994 (chapter 5). European Environmental Agency.

Egan, D., Howell, E.A., 2001. The Historical Ecology Handbook. A restorationist's guide on reference ecosystems. Island Press, Washington.

Elton, C., 1930. Animal ecology and evolution. Clarendon Press, Oxford, UK.

European communities, 2009. River basin management in a changing climate. Common implementation strategy for the Water framework directive (2000/60/EC) - Guidance document No. 24. European communities, p. 141.

Farina, A., 2000. The cultural landscape as a model for the integration of ecology and economics. Bioscience 50 (4), 313-320.

Fernandez, S., Bouleau, G., Treyer, S., 2014. Bringing politics back into water planning scenarios in Europe. Journal of Hydrology 518, Part A, 17-27. 
Fischer-Kowalski, M., 1997. On the development of concept and methodology of society's metabolism. Interuniversitäres Institut für interdisziplinäre Forschung und Fortbildung. Abteilung soziale Ökologie (version anglaise) (57).

Friberg, N., Bonada, N., Bradley, D.C., Dunbar, M.J., Edwards, F.K., Grey, J., Hayes, R.B., Hildrew, A.G., Lamouroux, N., Trimmer, M., Woodward, G., 2011. Biomonitoring of human impacts in freshwater ecosystems: the good, the bad, and the ugly. Advances in Ecological Research (44), 1-68.

Fulé, P.Z., Covington, W.W., Moore, M.M., 1997. Determining reference conditions for ecosystem management of southwestern ponderosa pine forests. Ecological Applications 7 (3), 895-908.

Gunderson, L.H., Holling, C.S., 2002. Panarchy: understanding transformations in human and natural systems. Island Press, Washington D.C., USA.

Hanski, I., 1999. Metapopulation Ecology. Oxford University Press.

Henri, C.P., Amoros, C., 1995. Restoration ecology of riverine wetlands: I. A scientific base. Environmental Management (6), 891-902.

Hering, D., Borja, A., Carstensen, J., Carvalho, L., Elliott, M., Feld, C.K., Heiskanen, A.-S., Johnson, R.K., Moe, J., Pont, D., Solheim, A.L., de Bund, W.v., 2010. The European Water Framework Directive at the age of 10: A critical review of the achievements with recommendations for the future. Science of the Total Environment 408 (19), 4007-4019.

Héritier, A., 1995. Leaders and Laggards in European Clean Air Policy, In: Waarden, F.v., Unger, B. (Eds.), Convergence or Diversity? The pressure of Internationalization on Economic Governance Institutions and Policy Outcomes. Ashgate, Aldershot, pp. 278-305.

Holling, C., 1973. Resilience and stability of ecological systems. Annual Review of Ecology, Evolution, and Systematics 4, 1-23.

Homeyer, I.v., 2004. Differential Effects of Enlargement on EU Environmental Governance. Environmental Politics 13 (1), 52-76.

Howarth, W., 2006. The Progression Towards Ecological Quality Standards Journal of Environmental Law 18 (1), 3-35.

Hughes, F.M.R., Colston, A., Mountford, J.O., 2005. Restoring riparian ecosystems: The challenge of accommodating variability and designing restoration trajectories. Ecology and Society (10), 1-12.

Hughes, R.M., Larsen, D.P., 1988. Ecoregions : an approach to surface water protection. Journal Water Pollution Control Federation (60), 486-493.

Jungwirth, M., Muha, S., Schmutz, S., 2000. Assessing the Ecological Integrity of Running Waters. Proceedings of the International Conference held in Vienna, Austria, 9-11 November 1998. Reprinted from Hydrobiologia, Vol. 422-423, Developments in Hydrobiology. Kluwer Academic Press, Dordrecht, p. 487.

Junier, S., Borowski, I., Bouleau, G., Interwies, E., Mostert, E., 2011. Implementing the Water Framework Directive: lessons for the second planning cycle, In: Quevauviller, P., Borchers, U., Thompson, K.C., Simonart, T. (Eds.), The Water Framework Directive: Action Programmes and Adaptation To Climate Change. RSC Publishing, Cambridge.

Kaika, M., Page, B., 2003. The EU water framework directive: part1 European policy making and the changing topography of lobbying. European environment 13, 314-327.

Karr, J.R., 1981. Assessment of Biotic Integrity using fish communities. American Fisheries Society 6 (6), 21-27. 
Kaufmann, M.R., Huckaby, L.S., Regan, C.L., J, P., 1998. Forest reference conditions for ecosystem management in the Sacramento Mountains, New Mexico. USDA Forest Service Rocky Mountain Research Station Fort Collins, CO.

Keessen, A.M., Kempen, J.J.H.v., Rijswick, M.v., Robbe, J., Backes, C.W., 2010. European River Basin Districts: Are They Swimming in the Same Implementation Pool? Journal of Environmental Law 22 (2), 197-221.

Kern, K., 1992a. Rehabilitation of streams in South-West Germany, In: Boon, P.J., Calow, P., Petts, G.E. (Eds.), River Conservation and Management. John Wiley \& Sons Ltd, Chichester, UK., pp. 321-336.

Kern, K., 1992b. Rehabilitation of streams in South-western Germany, In: Boon, P., Calow, P., Petts, G. (Eds.), River Conservation and Management. John Wiley \& Sons, Chichester, pp. 321335.

Knill, C., Liefferink, D., 2007. Environmental politics in the European Union. Manchester University Press, Manchester.

Kraemer, A., Klasing, A., Homeyer, I.v., 2004 The EU Open Method of Co-ordination: Risks \& Chances for Environmental Policy. Commissioned by the Austrian Federal Ministry of Agriculture, Forestry, Environment and Water Management, Conference 'Sustainable Development in an Enlarged Union - Linking National Strategies \& Strengthening European Coherence', Vienna, Austria.

Lévêque, C., Muxart, T., Abbadie, L., Weil, A., Leeuw, S.v.d., 2003. L'anthroposystème : entité structurelle et fonctionnelle des interactions sociétés - milieux, In: Lévêque, C., Van Der Leeuw, S. (Eds.), Quelles natures voulons-nous ? Elsevier, Paris, pp. 110-129.

Logez, M., Pont, D., 2013. Global warming and potential shift in reference conditions: the case of functional fish based metrics. Hydrobiologia (704), 417-436.

Loupsans, D., Gramaglia, C., 2011. L'expertise sous tensions. Cultures épistémiques et politiques à l'épreuve de l'écriture de la directive cadre européenne sur l'eau. Centre international de formation européenne | L'Europe en Formation 3 (361), 87-114.

Marzin, A., Archaimbault, V., Belliard, J., Chauvin, C., Delmas, F., Pont, D., 2012. Ecological assessment of running waters: do macrophytes, macroinvertebrates, diatoms and fish show similar responses to human pressures? . Ecological Indicators (23), 56-65.

Marzin, A., Delaigue, O., Logez, M., Pont, D., 2014. Uncertainty associated with river health assessment in a varying environment: the case of a predictive fish-based index in France. Ecological Indicators (43), 195-204.

Mondy, C.P., Villeneuve, B., Archaimbault, V., Usseglio-Polatera, P., 2012. A new macroinvertebrate-based multimetric index (I2M2) to evaluate ecological quality of French wadeable streams fulfilling the WFD demands: A taxonomical and trait approach. Ecological Indicators (18), 452-457.

Moss, B., 2008. The Water Framework Directive: Total environment or political compromise? Science of the Total Environment 400 (1-3), 32-41.

Nilsson, C., Jansson, R., Malmqvist, B., Naiman, R.J., 2007. Restoring riverine landscapes: the challenge of identifying priorities, reference states, and techniques. Ecology and Society 12 (1).

O'Neill, R.V., 2001. Is It Time To Bury The Ecosystem Concept? (With Full Military Honors, Of Course!). Ecology 82 (12), 3275-3284.

Oberdorff, T., Pont, D., Hugueny, B., Porcher, J.-P., 2002. Development and validation of a fishbased index for the assessment of 'river health' in France. Freshwater Biology (47), 1720-1734. Odum, E.P., 1953. Fundamentals of ecology. W. B. Saunders, Philadelphia, Pennsylvania, USA. 
OECD, 1993. Organisation for Economic Co-operation and Development (OECD) core set of indicators for environmental performance reviews. OECD Environment Monographs No. 83, Paris.

OECD, 1994. Indicateurs d'environnement : Corps central de l'OCDE. OCDE, Paris.

Omernik, J.M., 1987. Ecoregions of the Conterminous United States. Annals of the Association of American Geographers (77), 118-125.

Ormerod, S.J., Dobson, M., Hildrew, A.H., Townsend, C., 2010. Multiple Stressors in Freshwater Ecosystems. Freshw. Biol (55), 1-4.

Pardo, I., Gómez-Rodríguez, C., Wasson, J.-G., Owen, R., van de Bund, W., Kelly, M., Bennett, C., Birk, S., Buffagni, A., Erba, S., Mengin, N., Murray-Bligh, J., Ofenböeck, G., 2012. The European reference condition concept: A scientific and technical approach to identify minimallyimpacted river ecosystems. Science of The Total Environment 420 (0), 33-42.

Pickett, S.T.A., Cadenasso, M.L., 1995. Landscape Ecology: Spatial Heterogeneity in Ecological Systems. Science 269 (5222), 331-334.

Pimm, S.L., 1984. The complexity and stability of ecosystems. Nature 307, 321-326.

Pont, D., 2011. Water Framework Directive. Intercalibration Phase 2. River Fish European Intercalibration Group. Final Report to ECOSTAT, p. 105.

Pont, D., Hugueny, B., Beier, U., Goffaux, D., Melcher, A., Noble, R., Rogers, C., Roset, N., Schmutz, S., 2006. Assessing river biotic condition at the continental scale: a European approach using functional metrics and fish assemblages. Journal of Applied Ecology (43), 70-80.

Pont, D., Piégay, H., Farinetti, A., Allain, S., Landon, N., Liébault, F., Dumont, B., RichardMazet, A., 2009. Conceptual framework and interdisciplinary approach for the sustainable management of gravel-bed rivers: the case of the Drôme River basin (S.E. France). Aquatic Ecology (71), 356-370.

Radaelli, C.M., 2003. The Open Method of Coordination: A new governance architecture for the European Union? . Swedish Institute for European Policy Studies.

Salais, R., 2004. La politique des indicateurs. Du taux de chômage au taux d'emploi dans la stratégie européenne pour l'emploi (SEE), In: Zimmermann, B. (Ed.), Action publique et sciences sociales. Maison des sciences de l'homme, Paris.

Santbergen, L., 2013. Ambiguous Ambitions in the Meuse Theatre. Impact of the Water Framework Directive on collective-choice rules for Integrated River Basin Management. Radboud University of Nijmegen, Delft.

Sbragia, A., 1996. Environmental Policy: the Push-Pull of Policy-Making, In: Wallace, H., Wallace, W. (Eds.), Policy-Making in the Euroepan Union, 3rd edition ed. Oxford University Press, Oxford, pp. 235-255.

Scheffer, M., Carpenter, S., Foley, J.A., Folke, C., Walker, B., 2001. Catastrophic shifts in ecosystems. Nature 413 (11), 591-596.

Schmutz, S., Kaufmann, M., Vogel, B., Jungwirth, M., Muhar, S., 2000. A multi-level concept for fish-based, river-type-specific assessment of ecological integrity, In: Jungwirth, M., Muhar, S., Schmutz, S. (Eds.), Assessing the Ecological Integrity of Running Waters. Kluwer Academic Publishers, Dordrecht, pp. 279-289.

Scott, J., Trubek, D.M., 2002. Mind the Gap: Law and New Approaches to Governance in the European Union. European Law Journal 8 (1), 1-18.

Steyaert, P., Ollivier, G., 2007. The European Water Framework Directive: How Ecological Assumptions Frame Technical and Social Change. Ecology and Society 12 (1), 25 [on line]. 
Stoddard, J.L., Larsen, D.P., Hawkins, C.P., Johnson, R.K., Norris, R.H., 2006. Setting expectations for the ecological condition of streams: the concept of reference condition. . Ecological applications 16 (4), $1267-1276$.

Suding, K.N., Gross, K.L., Houseman, G.R., 2004. Alternative states and positive feedbacks in restoration ecology. Trends in Ecology and Evolution 19 (1), 46-53.

Swetnam, T.W., Allen, C.D., Betancourt, J.L., 1999. Applied historical ecology: using the past to manage the future. Ecological Applications 9 (4), 1189-1206.

Tansley, A.G., 1935. The use and abuse of vegetational concepts and terms. Ecology 16, 284307.

Turnhout, E., 2009. The effectiveness of boundary objects: the case of ecological indicators. Science and Public Policy 36 (5), 403-412.

U.S. House of Representatives, 1972. Report of the Committee on Public Works, United States House of Representatives, with additional and supplemental views. H.R. 11896 to amend the Federal Water Pollution Control Act, 92nd Congress, 2nd session. House Report 92-911, U.S. Government Printing Office, Washington, D.C., USA.

Wallin, M., Wiederholm, T., Johnson, R.K., 2003. Final guidance on establishing reference conditions and ecological status class boundaries for inland surface waters EU Common Implementation Strategy (CIS) for the Water Framework Directive.

Whittaker, R.H., 1975. Communities and Ecosystems. Macmillan Publishing Co., New York. Wright, J.F., Furse, M.T., Armitage, P.D., 1993. RIVPACS: A technique for evaluating the biological quality of rivers in the UK. Eur. Water Pollut. Control (3), 15-25. 